\title{
Criatividade e história, entre a ação e o discurso
}

Maria Luiza Martini*

\begin{abstract}
Resumo. O artigo parte de uma investigação das formas narrativas mais difundidas numa comunidade pouco letrada. $O$ teatro, opção preferida pela comunidade onde se situou o estudo - Vila Pinto (Viamão/RS) - revelou-se tanto um instrumento comemorativo quanto uma forma de expor problemas. Assumimos então a hipótese de que o teatro épico poderia desenvolver potencialidades dessa forma narrativa enquanto escrita da história, por meio de uma parceria de texto e encenação, com um grupo de adolescentes, para contar a história do espaço público mais antigo da cidade, a Rua da Praia. O resultado é a construção de uma identidade transcendental, o grupo de teatro, que produz dois textos: o primeiro ficcional e o segundo, seu comentário historiográfico.
\end{abstract}

Palavras-chave: Fronteiras historiográficas. Teatro épico.

Narrativas populares.

* Professora do Departamento e do PPG em História da UFRGS.

Anos 90, Porto Alegre, v. 12, n. 21/22, p.333-367, jan./dez. 2005 
Criatividade e história, entre a ação e o discurso

\section{Introdução}

O trabalho que apresento neste artigo procura duas inserções. A primeira de caráter teórico, na historiografia denominada "Nova História Cultural", e a segunda, na história da Cultura Brasileira dos anos sessenta.

A relação entre historiografia (discurso), criatividade e história (ação) é o que fundamenta o nome Nova História Cultural. Assim o é por dirigir-se ao imaginário em sua produção mais genuína: a expressão artística, seja qual for sua qualidade. Documentos dessa natureza, da imagem à narrativa, seriam indícios da cultura, do código, de um dado contexto histórico.

Leenhart, um artífice dessa história cultural, ao analisar um clássico da literatura brasileira, Jorge Amado, apresenta e ensina como usar seus instrumentos de trabalho.

A literatura de ficção, considerada como documento histórico, desempenha efeito em dois planos: primeiro, aquele da expressão de teses ou idéias por um narrador mais ou menos onisciente. Neste caso ela dá uma formulação clara aos discursos que provêm desta cultura, do explícito, ao qual o historiador gostaria de permanecer. Por outro lado, ela é o teatro daquilo que faz, realmente o corpo da ficção: a ação. A ação não é um discurso. É mesmo difícil de reduzi-la ao discurso pois, precisamente, o modo de agir dos personagens do romance permanece infra-lingüístico, infradiscursivo, submetido a imponderáveis, a contradições, a contingências, a tudo aquilo do qual o discurso tem horror. Eles agem e, entretanto, esta ação tem um sentido! (Leenhardt, 2004, p 147).

Isto é, literatura (do cordel, do folhetim de jornal ao romance), teatro (do "casamento na roça" ao teatro épico), cinema, artes plásticas (da tela à pichação num muro qualquer) explicitam, do- 
cumentam a existência do imaginário, do infra-lingüístico. Portanto, tais documentos trazem o signo, a metáfora para dentro da historiografia. Ao historiador cabe decifrá-los, articular discurso e ficção, produzir um sentido e integrá-lo à sua própria construção.

Consideramos que, assim como a produção artística, a evocação de outros tempos e culturas por seus atores sociais, por meio de entrevista gravada ou registro etnográfico, constitui uma literatura de quem nunca fez literatura, um documento portador de ação. Pessoas que concedem entrevistas de sentido biográfico ou depoi-

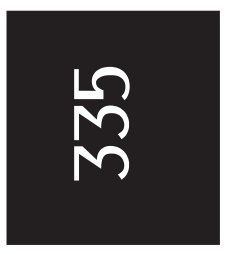
mentos sobre sua própria história, falam porque desejam falar para a história. Se o historiador for capaz de escutar, provavelmente, no momento de titubeio, ou do discurso-padrão do depoente, poderá inserir um simples "Foi mais ou menos quando?", "Não entendi, quem é X”. Com o que a pessoa-fonte, freqüentemente, volta à evocação, ao reviver do acontecimento. Quando? No ato? Logo depois da entrevista, gravador já desligado? Na próxima entrevista, quem sabe?... Particularmente penso que um material adequado a uma documentação oral é o de "quadros sociais da memória" (Halbwachs, 1990): um arquivo de informações e emoções que orientam nossa percepção, que nos faz ver ou ignorar, que é um sem-número de outros, de influências, num mesmo indivíduo, que faz social a memória de qualquer um. São grupos de convívio e a produção cultural - músicas, livros, filmes, programas de TV, piadas, artistas, políticos preferidos etc. E assim aparecem, nos testemunhos sobre um dado tempo, imagens, signatárias de modelos para ser...

Entrevistar por meio da produção cultural, entretanto, é seguir um caminho que permite à pessoa-fonte mostrar-se preservando-se, tanto aquela convicta de pertencer à história quanto as que se descobrem na história pela relação com a pesquisa. Uma música, um programa de TV, pode ser suporte para evocação, permitindo avançar sobre o esquecimento. 
Criatividade e história, entre a ação e o discurso

A narrativa em que se produz a evocação é aberta, preservando a produção de sentido. É por isso que, nos anos 20, Benjamim considera-a historiográfica, capaz de fazer uma leitura da opressão e da fragmentação. É como Scheherazade, salvando sua vida a partir do "movimento infinito da memória, notadamente popular"; ou de Proust, que, em sua evocação, busca do passado no presente e o "presente que já está lá, prefigurado no passado"; ou de Kafka, em seus retalhos de sonho e pequenas histórias, escapadas ao esquecimento.

Ao analisar o processo histórico, Benjamin dirige-se à historiografia:

Pensar não inclui apenas o movimento das idéias, mas também sua imobilização. Quando o pensamento pára bruscamente, numa configuração saturada de tensões, ele lhes comunica um choque, [...] através do qual essa configuração se cristaliza enquanto mônada [...], sinal de uma imobilização messiânica dos acontecimentos. (Benjamin, 1996, p. 231).

Em outras palavras, seria a crise reveladora da estrutura numa conjuntura. Mas ele não quer essas palavras. Quer iluminar a leitura do real enquanto processo evocativo, onde presente e passado se encontram produzindo efeito épico: distância crítica dentro do imaginário - imagem da história como imagem de si mesmo messiânica.

O historiador de Benjamin analisa ao selecionar fatos, ao urdi-los, explicando-os apenas no limite do necessário ao trabalho historiográfico. Usando a "liberdade do cronista, para tratar de grandes e pequenos fatos" (Benjamin, 1996, p. 223), seja da revolução industrial, da guerra ou do modo das mulheres mandarem mensagens por seus penteados, seria possível narrar a experiência coletiva da fragmentação. Justamente o que escapa ao determinismo da história "progressista". Ela liquida com a profusão de sentido ao eleger uma totalidade, o progresso cientificamente previsível.

Anos 90, Porto Alegre, v. 12, n. 21/22, p.333-367, jan./dez. 2005 
Intérprete da modernidade, Benjamin opta por uma escrita da história capaz de preservar a profusão de sentidos que vem da fragmentação, um historiador próximo a Heródoto:

[...] não explica nada. Seu relato é dos mais secos [...] Por isso, sua narrativa da história se assemelha a essas sementes de trigo que durante milhares de anos ficaram fechadas hermeticamente nas câmaras das pirâmides e que conservam suas forças germinativas. (Benjamin, 1996, p. 204).

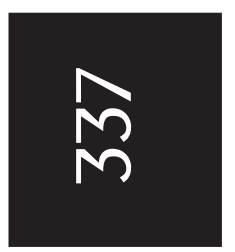

Essa opção implica, para a Historiografia, aproximá-la da literatura, levando seu discurso à beira do imponderável. História e literatura:

[...] se aproximam, por serem ambas modalidades de representação do real e por serem ambas ficção, no sentido da recriação do concreto vivido [...], mas dentro de um "delírio autorizado", mais restrito do que aquele que rege a criação ficcional literária. [...] Ou seja, a história é também o domínio do imaginário [...] sonho, utopia, inconsciente coletivo e também da ilusão do espírito, intenções deliberadas, seduções ideológicas. O imaginário é, por vezes, um real mais real do que as condições concretas da existência [...] Enquanto representação, o imaginário enuncia, se reporta e evoca outra coisa não explícita e não presente. (Pesavento, 1995, p. 2).

Olhando por meio desses referenciais a cultura brasileira dos anos sessenta no Brasil, encontramos uma produção ficcional que constitui rica documentação para a história cultural. Floresceu nos centros urbanos, reunindo questões tais como "quem é o povo brasileiro" e o teatro épico de Brecht.

Propondo uma dramaturgia e uma poética de espetáculo peculiar, o teatro épico intensifica a profusão de sentido, típica de qualquer encenação, sempre tríplice. É dramaturgia, texto, interpretação 
Criatividade e história, entre a ação e o discurso

do diretor, reinterpretada pelo ator. É espaço e cenário. Também território infraverbal, suporte da interpretação, o corpo do ator aciona a complexidade, divergindo ou acrescentando ao texto sentimentos, nuances, pela postura, pela voz, pelo olhar.

O épico é uma nova poética de espetáculo, isto é, uma outra concepção física do palco, de encenação e atuação; também é uma nova dramaturgia. Sua base é o teatro popular naquilo que ele tem de mais universal e próximo das origens do próprio teatro, a sucessão de quadros (Barthes, 1984), típica da procissão dionisíaca que vai encenando a vida do deus em seu percurso. A rigor, cada quadro vale por si mesmo, independente do que possa representar na sucessão.

Os quadros podem ser suspensos ou "congelados" (expressão de Benjamin) pelo público, pelos atores, pela encenação, que em geral utiliza cortinas musicais para fazê-lo. Cria-se um espaço para comentários, discussão de cena, reencenação diversa, publicação de outras informações, projeção de imagens ou contraposição de outro quadro. Nada é intocável, nem a dramaturgia; cada texto vale para cada encenação. É como se o carnaval, o teatro de revista ou um relato de esquina, fossem relidos, na sua estrutura, para mostrar produções de sentido social. Assim dramaturgia, a trama e o personagem do teatro épico trazem ao público um meio e um tipo social em demonstração, em análise.

A essência do distanciamento crítico é que não há ação, senão a narração da ação, demonstrada por atores. Isto leva a tipos, em alguns momentos, só em alguns momentos, caricatos. $\mathrm{O}$ ator que representa vendo-se a si mesmo representando um gerente, por exemplo, coleciona metáforas, cria um estudo sobre esse tipo. Torna-se um quase erudito sobre gerentes. A cena pode ser congelada para fazer emergirem informações e explicações sobre o tipo ou aspectos da situação social em questão.

A orquestra desaparece do palco épico. Não há mais separação entre o público e a platéia, além de uma pequena elevação. É

Anos 90, Porto Alegre, v. 12, n. 21/22, p.333-367, jan./dez. 2005 
a tribuna. Há espaço para todos os discursos: estatísticas num telão, história, política, filosofia etc. Eles se rompem pelo debate, pela vaia, inclusive pelo esvaziamento ou pela decisão dos atores de voltarem à cena, ou o que mais seja. Assim, há espaço mais para a ironia, é verdade, mas também para a utopia...

O objetivo didático, no teatro épico, é uma contingência. A tese é o objetivo, o prazer socrático de pensar, um pensar diverso, que parte dos interesses aos quais as massas estão "coladas", nos termos de Brecht. Ele desejava "[...] ter um teatro cheio de especialistas, da mesma forma que um estádio esportivo está cheio de especialistas" (Benjamin, 1996, p. 81) analisando a partida, o time e o técnico. Os proletários eram os clientes habituais do seu teatro "enfumaçado". Para eles não haverá nada de surpreendente na exigência feita por Brecht a um ator da Ópera dos Três Vinténs de representar de tal maneira a cena da escolha da perna de pau, por seu personagem, mendigo, que só por causa desse número as pessoas decidam voltar ao teatro, no momento em que a cena é representada (ibid., 1996, p.83).

Durante os anos 60, no Brasil, o teatro se aproximava do épico, pelo espetáculo em sucessão de quadros, a polivalência dos atores como narradores (sistema coringa) e, esporadicamente, pela atuação com distanciamento crítico. Mas havia poucos espaços em Arena (a tribuna), a convivência dos atores com o público não acontecia entre o congelamento das cenas, muito menos com a pluralidade exuberante de discursos e recursos do teatro "enfumaçado" de Brecht. Em geral, acontecia ao final do espetáculo com o previsível, às vezes constrangedor, debate. Preservava-se o ritmo e a unidade, o efeito mágico do espetáculo realista. $\mathrm{O}$ ator continuava dominando a cena, emitindo a mensagem.

Mas havia uma sintonia épica, um encontro entre passado e presente operado no imaginário coletivo, encontro dos dois brasis, do sertão e do urbano. Essa sintonia profética constituía uma narrativa de si mesmo, onde o justiceiro do passado, um cangaceiro, 
Criatividade e história, entre a ação e o discurso

Joãozinho Bem-bem (Guimarães Rosa, 1984), se funde com João Boa Morte, um justiceiro coletivo, o Cabra marcado para morrer: "Que é entrando para as Ligas/ que ele derrota o patrão / que o caminho da vitória está na revolução" (Ferreira Gullar, 1983). De fato, João é herói e outros tantos. Quem entrava na liga sabia disto: Boa Morte era "um de todos" se caísse na emboscada. O poeta buscava apoio nos centros urbanos para os Boa Morte. E também buscava a auto-estima do homem excluído pela "justiça", reconhecendo seu poder de trabalho e criação. "Se a mão livre do negro tocar na argila, o que é que vai nascer? Vai nascer [...]. Nasce estatuinha bonita de se ver." (Guarnieri, 1965). Esse teatro "quase épico" "ancorava-se numa base bem real, a insurgência dos trabalhadores rurais" (Ridenti, 2003, p.141). Bem real: é a ULTAB, nacionalmente, o MASTER no RS, Trombas e Formoso em Goiás, as Ligas Camponesas no Nordeste entre outros. Essa base de realidade foi a primeira vítima do golpe, quando operários, camponeses, militares, partidos políticos e o próprio estado, sofreram imediata e eficiente "limpeza" por meio da repressão. Ainda não burocratizada, sua ação não foi menos brutal e estratégica. O ano de 1968 marca a repressão sobre as elites intelectuais. Aquela que desmontou os atores populares de um processo civilizador, uma sociedade e um cidadão nascentes ocorreu em 1964...

A extrema tentativa, seja da cena aberta do teatro épico e da relação com o homem do povo, do coração do Brasil, é Gracias Senior (Teatro Oficina). Aconteceu, segundo essa precária evocação, primeiro no sertão e depois em São Paulo. Apresentava-se em dois dias. Durava ao todo em torno de oito horas ou mais. Narrava o que aconteceu no sertão, sem João Boa Morte. O espetáculo protagonizado com os sertanejos foi gravado. Sua projeção entremeava-se ao espetáculo urbano, estimulando propostas de cooperação e solidariedade feitas à platéia, por meio de jogos semelhantes aos de auditório, criando situações em que os participantes dependiam uns dos outros. Essa também era a temática do espetáculo no sertão.

Anos 90, Porto Alegre, v. 12, n. 21/22, p.333-367, jan./dez. 2005 
Era um pequeno povoado, à beira de um braço de rio temporário. Isolado na época das chuvas. Atravessar, só de bote ou com água acima da cintura. Os atores, vestidos com túnicas, semelhantes às usadas em procissões religiosas, se dirigem à capela recitando textos como se fossem preces. Honram os santos. São observados pelos habitantes do povoado à distância. O mesmo acontece em visita ao cemitério. Honram os mortos. Depois, os atores iniciam a construção de uma ponte. Trabalham sempre juntos, numa espécie de procissão. Depois, um grupo de habitantes apa-

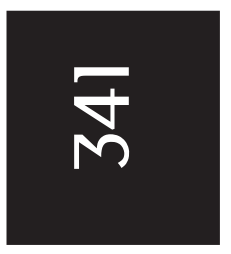
rece entremeado aos atores. Trabalha com eles. A câmera se aproxima. Uma dupla ri e esconde o rosto. Outro parece ensinar um passo de dança.

Salvo engano, nesta evocação, era início de 1974. Voltei a São Paulo para ver o novo trabalho do Grupo Oficina. Montava Tchekov, As Três Irmãs. Não lembro o personagem interpretado por José Celso. Num balanço, praticamente sem quebrar o ritmo do embalar-se, quebra o texto no meio da frase. Diz: "eu quero voltar pr'o sertão, voltar pr'o sertão”. Desfaz-se o espetáculo.

Gracias Senior, um teatro integralmente épico, protagonizado pelos atores e o público, realizara um fugaz encontro entre atores dramáticos e atores sociais dentro do espetáculo, numa proposta próxima à do Living theater, ${ }^{1}$ mas peculiar, voltada para o deciframento do sertão. Essas concepções também se farão presentes nas Ciências Humanas (Antropologia, História e Sociologia). Trata-se de colocar a linguagem no centro da pesquisa, partindo de referencias tais com: a palavra é equivalente ao desejo e à ação; a evocação é um acesso ao esquecimento e ao fragmentário; o tempo é humano quando narrado. Trata-se de criar acesso à palavra dos atores sociais pela interlocução, na busca dos códigos culturais, que informam o imaginário dos atores sociais e dos atores dramáticos.

No fim dos anos 70, ainda período autoritário, o trabalho acadêmico na área de Ciências Humanas, a partir do modelo 
Criatividade e história, entre a ação e o discurso

antropológico preexistente a essas questões, conversa com as pessoas, "homens do povo", em geral. Não são encontros públicos. São conversas protegidas pelo anonimato, registradas etnograficamente em diários de campo, ou preferencialmente gravadas, no caso da história oral. Depois da anistia surgem aqui e ali depoimentos identificados, expressamente sobre crimes contra humanidade, à semelhança dos depoimentos de vítimas do holocausto.

O desenvolvimento desse tipo de pesquisa gera documentos do imaginário, biografias, romances e filmes polêmicos com inegável protagonismo popular, como é o caso de "Cidade de Deus", recentemente.

Nessa direção do imaginário, constituído especificamente como objeto pela Nova História Cultural, e da história recente da cultura brasileira, procurei contar uma história envolvendo protagonismo cultural, memória e evocação, sob controle de um critério preciso. Para tanto, em sintonia com as demais referências, buscamos esse critério em Ricoeur, na perspectiva de que o tempo torna-se humano quando narrado.

\section{História, protagonistas, historiografia}

Desde o início desta história, tratei de colocar-me no contexto de uma observação participante, visando formar uma parceria de narradores, com um grupo de adolescentes, para contar uma história voltada ao público juvenil popular. O objeto deste trabalho, portanto, é analisar esse processo e seus produto segundo limites historiográficos. Contar a Beira Rio, a Rua da Praia, por onde passam as origens de Porto Alegre, levou-me a um grupo de quatorze adolescentes da escola José Mariano Beck, numa área de risco social, a Vila Pinto, na Grande Bom Jesus.

$\mathrm{O}$ direito às terras de uso comum e uso público, onde se inscrevem a praia e o porto, o impacto do Tratado de Madri (1750)

Anos 90, Porto Alegre, v. 12, n. 21/22, p.333-367, jan./dez. 2005 
e da invasão espanhola (1763) sobre o povoamento do Rio Grande do Sul, a tradição do "concelhismo" português na cultura dos casais açorianos abrigados à beira do rio, o relacionamento com o reino por intermédio das "representações" (abaixo-assinados), a fertilidade social no interior da irmandade e da capela (ajuda mútua, organização local) deram vida a uma vertente comunitária de organização municipal (a freguesia), em contraste com a militar (fortes, presídios). É quando os casais finalmente, em 1772, recebem as terras prometidas pelo rei mas perdem o padroeiro de sua

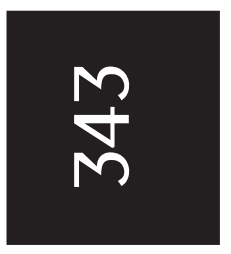
irmandade, São Francisco de Chagas, para a santa do vice-rei, Nossa Senhora da Madre de Deus. Em palavras do dito popular, "despiram um santo para vestir outro".

Qualquer história é sujeita a novos achados, mas a história de origens é particularmente aberta: por responder à questão de uma comunidade sobre si mesma - de onde vim? -, porque sua documentação é sujeita às vicissitudes do tempo, a conflitos que cercaram seu surgimento na época e, quem sabe, a "luta pela memória" entre diferentes versões da identidade e nascimento da cidade. Documentos referidos na década de quarenta, sem enunciação completa das fontes, até agora não foram localizados. Há falta de páginas em livros de registro.

Quem sabe dessa história de origens? De suas versões? É preciso contá-la, de tempos em tempos, para "galeras" como a do Mariano Beck.

"A referência por meio de vestígios retira algo da referência metafórica comum a todas as obras poéticas, na medida em que o passado só pode ser reconstruído pela imaginação" (Ricoeur, 1994, p. 125). A história é uma probabilidade. Isola e interroga um conjunto de vestígios, do ponto de vista da causalidade narrativa (um por causa do outro) e da causalidade explicativa (análise de fatores ou leis probabilísticas). Portanto, o passado, enquanto vestígio e probabilidade, é parte da imaginação. 
Criatividade e história, entre a ação e o discurso

Essa abertura historiográfica constituiu minha perspectiva inicial: apresentar o princípio de realidade, o conjunto de vestígios organizados (documentos e referências) segundo a dupla causalidade, narrativa e explicativa, sobre a história da Rua da Praia, primeiro espaço público delimitado na cidade, numa narrativa apreciada pelo público juvenil, representado pelos adolescentes do Mariano. ${ }^{2}$

Que narrativa? Para apreendê-la, estabeleci um processo de observação participante - compartilhar consciente e sistematicamente interesses e afetos de um grupo, numa atividade. Minha identificação como pesquisador definiu-se por ser professora da UFRGS e por situar-me na Escola Municipal, com o objetivo de formar um grupo caracterizado por regularidade na freqüência e na relação idade/série escolar, disponível para atividades extraclasse.

O trabalho gerou o texto escrito com a participação do grupo, assim como uma tese de doutoramento. Este artigo resume tais resultados, incorporando questões colocadas pela banca, nesse momento privilegiado de análise, que é a defesa de uma tese.

\section{Narrativas da vila}

Deixei-me transitar entre a Escola e a Vila, relacionando-me com os adolescentes e a população ao sabor da interpretação e das demandas do contexto. Procurava perceber motivações, elaborar o estranhamento e criar vínculos. Esse primeiro processo resultou em atividades culturais, dando forma a um estudo exploratório que nos permitisse identificar as narrativas mais aceitáveis para o grupo, procurando delimitá-las historiograficamente. Tanto pela via da escola quanto pela comunidade, a opção de atividade cultural foi o teatro ("vamos fazer um teatro?"), impondo-se sobre outras propostas - entrevistas sobre a história de adolescentes (“já 
tem história da vila"; "aqui na vila todo mundo se conhece, vão saber quem é") ou sobre a história da cooperativa ("a gente já deu entrevista").

Há indícios de que o gosto pela dramatização vincula-se a divertimentos tradicionais, sazonais: o casamento da roça na festa de São João, o presépio vivo no Natal e o enredo da escola de samba no carnaval. O "teatro" é muito valorizado em comemorações escolares e cívicas, associando-se à "história". O mesmo acontece na comunidade, especialmente para a inauguração de equipa-

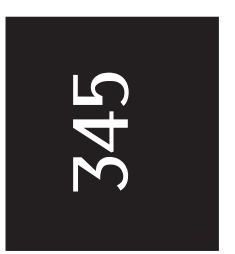
mentos sociais.

A improvisação teatral também é um recurso didático utilizado freqüentemente como estratégia escolar para explicar idéias, estimular a comunicação, a participação, tratar da aceitação de normas e problemas de relacionamento.

O "vamos fazer um teatro" apresenta um discurso característico, aberto à organização de quadros, perceptível em várias “encenações" populares.

Um desfile da escola de samba, uma grande festa coletiva, uma espécie de teatro originário, também é uma procissão, com enredo marcado por tema musical, desdobrando-se em várias alegorias, quadros dançados por seguidores apresentados à multidão.

Organizamos, a pedido da escola, um casamento na roça e um presépio vivo. O casamento na roça, das festas juninas, é uma improvisação dramática, satírica, por quadros, em procissão semelhante à via sacra, ou à procissão dionisíaca. O público da festa já espera, sabe como se comportar e participar da apresentação. No meio da folia, a história da reparação da honra é representada em paradas, de grupo em grupo, de episódio em episódio, com a participação do público, modificando-se a cada vez (o noivo que dispara é agarrado, a noiva grávida desmaia, um convidado apresenta-se para casar no lugar do noivo e outros incidentes que os participantes podem inventar ao longo do percurso). Temos indícios de que antes do "som" (alto volume, estéreo) haveria mais 
Criatividade e história, entre a ação e o discurso

texto. Agora a ação termina predominando sobre o texto, já que as vozes são abafadas pela música.

O presépio vivo é um ritual piedoso. Apresenta uma característica de relativa unção. $\mathrm{O}$ "som" é natalino. O vozerio diminui. Os personagens que movimentam a apresentação são os anjos, os pastores e os reis magos, que vão chegando para visitar e presentear o Menino Deus. Cada chegada com o presente é um pequeno quadro.

Esse também é o perfil do "teatro" de aula, de reflexão e de festa. Sempre há um narrador, apresentador da comemoração: ele anuncia, explica, avisa, prescreve e faz comentários edificantes. Quando o "teatro" se apresenta, há um narrador eventual que faz a ligação entre as cenas, atua como cortina (o tempo passou) e explica ligações que não são evidentes. $\mathrm{Na}$ comunidade, na cooperativa de reciclagem, identifiquei sinais mais recentes do teatro apreendido como técnica de mobilização experimentada por uma de suas líderes.

No estudo exploratório, os adolescentes escolheram "fazer um teatro" sobre adolescência e violência, por força do próprio problema e talvez pela campanha recentemente desenvolvida na Escola. O pessoal da Cooperativa de Reciclagem desejava "fazer um teatro" para comemorar a inauguração de um novo galpão.

Minha pergunta inicial na Cooperativa - "como se recicla?" - levou-nos à organização do trabalho enquanto discurso, isto é, como "coordena" (fala de meus parceiros) a vida das pessoas envolvidas e também nos levou ao sentido da reciclagem, a "salvação da natureza".

O grupo de adolescentes talvez preferisse, se estivesse habilitado, uma forma afim como o rap. Mas de qualquer maneira, também seria épica e dramática: vivenciar, agir na aquisição da informação. Iniciamos a criação da história de vida de duas meninas: da escola, a droga, até a recuperação, por meio da improvisação dramática.

Anos 90, Porto Alegre, v. 12, n. 21/22, p.333-367, jan./dez. 2005 
A partir dessas observações, consideramos que o teatro, naquele contexto, constitui um código narrativo tanto ficcional quanto discursivo, adequado a uma euforia constante. Esta euforia não é exclusividade da vila, mas é característica, contrastando com a privação e instabilidade da pobreza, num espaço habitado por pessoas com pouca renda. Adultos, jovens e crianças partilham essa euforia, marcada em geral pelo ritmo e pela dança. Ambos são uma espécie de objeto transicional para o que não se quer lembrar. Eventualmente as letras das músicas,

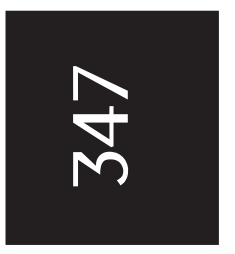
especialmente o rap, referem o que deve ser esquecido, aquilo a que não se dá nome porque "chama" (pobreza, violência). Códigos de escuta, isto é, onde e quando não se deve falar ou fazer barulho são escassos. Mesmo quando se trata de assuntos cruciais, em que há debate, como organização de trabalho (horários, produtividade) na cooperativa, por exemplo, a atenção não se mantém por muito tempo.

O ritmo, as danças, a "gozação", ao mesmo tempo em que tecem a euforia, minimizando evocação e análise, são seus códigos de acesso. Nessa situação, o teatro é um objeto transicional e um "quase código" de acesso ao que é doloroso. O personagem, máscara protetora, permite transitar pelo sofrimento e olhar a si mesmo. Improvisar concentra, produz leitura do outro, da intriga, pela força da ação. "Fazer um teatro", colocar-se num personagem, no mais inocente "faz de conta" (mimesis), produz um primeiro efeito de distância mínima necessária de si próprio para transformar-se, ser uma outra narrativa e contracenar, relacionar-se: "como vejo o outro, como imagino que o outro me vê".

\section{Teatro épico e historiografia}

Ricoeur distingue a narrativa histórica por criar uma intriga que não é intriga, a "quase intriga", gerada por uma "imitação da 
Criatividade e história, entre a ação e o discurso

vida" específica e protagonizada por personagens que não são personagens individualizados mas coletivos, "quase personagens".

Sentimentos e ações de indivíduos interessam aos historiadores enquanto referência à natureza, a um tempo, lugar e mudanças sociais. O "quase personagem" é uma entidade historiográfica indecomponível e coletiva (a cultura, a sociedade, a nação, a comunidade, o grupo etc.), contemplando obliquamente os indivíduos que a integram. Comporta-se na cena histórica como um grande indivíduo, ao qual o historiador pode atribuir, como se fosse entidade singular, a iniciativa de certos cursos de ações e a responsabilidade histórica de certos resultados, mesmo não intencionalmente visados. A própria técnica narrativa, que destaca o personagem do indivíduo, gera essa transferência no plano sintático, para o discurso histórico. O personagem coletivo (os brasileiros, o indígena, o açoriano etc.) toma o lugar do personagem que o indivíduo representa em outras narrativas. ${ }^{3}$

Esse é o ponto em que a narrativa, como um todo, se encontra com sua própria história. Poesia, ficção e historiografia constituíram-se historicamente, pelo menos na Cultura Ocidental, enquanto gêneros literários, expectativas, orientações específicas para autores e leitores. Se alguém quer saber de história vai buscar um historiador e não um dramaturgo. Uma forma de narrar está articulada a "regras, normas; é, desde sempre, simbolicamente mediatizada". (Ricoeur, 1994, p 91).

O teatro inscreve-se, assim como o romance, no que Veyne (1984) chama de ressurreição, não de uma construção histórica. Pertence ao mundo do personagem e da intriga, enquanto a historiografia detém-se no "quase personagem" e na "quase intriga", onde o indivíduo aparece obliquamente focado, sob o olhar do historiador, nas entidades históricas (os escravos, os sesmeiros, os homens livres etc.). Portanto, a narrativa mobilizadora de meus parceiros, observada nos limites do estudo exploratório, estaria longe, senão em oposição à historiografia.

Anos 90, Porto Alegre, v. 12, n. 21/22, p.333-367, jan./dez. 2005 
A partir dessas observações, levantei a hipótese de que o Teatro Épico, de Brecht, anteriormente caracterizado, poderia aproximar a narrativa teatral da historiográfica, com base nos efeitos de distanciamento crítico e congelamento (interrupção). Assim como o quase personagem de Ricoeur relaciona-se obliquamente com indivíduos, o indivíduo do personagem de Brecht relaciona-se obliquamente com quase-personagens, isto é, com tipos sociais. Considerei possível criar uma narrativa dramática próxima da historiográfica, partindo da dramaturgia épica produzindo efei-

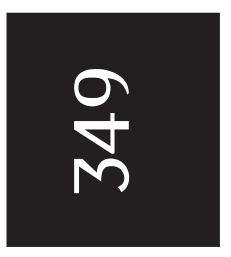
tos históricos e historiográficos, em que um narrador (o historiador) partilha a narração com personagens sociais.

A relação autor-leitor é uma comunidade cultural implícita, pelo partilhar de alguns paradigmas comuns a ambos. Isso permite ao leitor, cúmplice do autor, completar a obra no seu próprio mundo. Tratava-se, portanto, de transferir a cumplicidade que tínhamos sobre intriga e personagens, no "vamos fazer um teatro", para a ação social e os tipos sociais do teatro épico, indivíduos posicionados obliquamente à "quase - intriga" e ao "quase - personagem" da historiografia, organizados pelo historiador - narrador.

O narrador do texto é o historiador, que também é o diretor do espetáculo. Ele constrói pouco a pouco a operação probabilística, dispondo hipóteses, indícios e lacunas, como análise e interpretação, no comentário e ligação das ações. Atua, assim, como o outro, o estranho, constituindo-se em recurso de distanciamento crítico, fundamental ao Teatro Épico.

\section{A parceria}

Em qualquer relação intersubjetiva existe confronto de identidades que se revelam em contraste, na rotação recíproca da posição de sujeito para objeto, isto é, do poder. Desde o estudo exploratório o pesquisador adulto, letrado, "de bairro", silencioso, 
Criatividade e história, entre a ação e o discurso

confrontou-se, por exemplo, com o grupo adolescente, iletrado, "de vila", ruidoso, produzindo estranhamento e relações de poder, a serem elaboradas desde o objetivo de "fazer um teatro".

Trabalhei com a hipótese de que a identidade se move; é um perfil característico flutuante; de que estranhamento e relações de poder poderiam se equacionar pela criação de uma identidade terceira, o grupo de teatro, capaz de minimizar conflitos entre os participantes e o pesquisador. O "vamos fazer teatro", ocasional na sala de aula e nas festas, seria transferido para uma oficina que também seria de história. Contava que personagens de outro tempo e um espaço popular, reunindo presente e vestígios do passado, a Rua da Praia, produzissem um processo singular, evocativo dos dois tempos. Esperávamos que se criasse uma identidade transcendente, que se fragmentaria como qualquer outra, mas que fosse capaz de nos reunir além do estranhamento.

O movimento da identidade, a relativa estabilidade de um perfil individual e social também dependem da internalização de referências culturais, significações incorporadas à própria ação (Ricoeur, 1994, p.92) Essas referências partilhadas produzem uma comunidade cultural, sobre as quais é possível estabelecer acordos e vínculos entre atores sociais. Por exemplo, quem trabalha recebe pelo seu trabalho. Considerando este aspecto, explicitei para o grupo a natureza, os objetivos e os recursos do projeto a ser desenvolvido.

Desenvolver uma oficina de teatro e história para fazer um livro exigiria tempo, não faltar e chegar na hora, diferente de "fazer um teatro curtinho, de festa". Seria trabalho. O livro seria financiado por um convênio entre a UFRGS e o Município. Faríamos uma parceria pelo tempo necessário para produzir o livro e a apresentação da peça. Quem chegasse ao fim receberia direito autoral. Também fazia parte do acordo um lanche para cada sessão de trabalho. 
O espaço das escolas não é programado para atividade extra-classe. Não existe uma sala grande, separada, independente das salas de aula, que possa comportar o ruído adolescente. Freqüentemente a identidade transcendente se quebrava, pois meus parceiros deixavam de lado os açorianos para improvisar a si próprios. Aprendi muito com eles e sobre eles, nesses momentos de grande ruído, inviabilizando a aula das professoras vizinhas. Fomos expulsos três vezes.

A constante experimentação, típica dos adolescentes de qual-

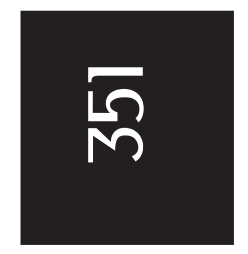
quer classe social, envolve transgressões a regras e normas (barulho, escrever pelas paredes, achar e comer pirulitos que não lhes pertencem, riscar palavrão na cadeira); freqüentemente perturbam, desestabilizam emocionalmente os adultos (eu não seria exceção), predispondo-os a vê-los e tratá-los como marginais que devem ser excluídos do convívio, tanto quanto se fossem surpreendidos traficando drogas. Diz-se: "Não merecem!", "Recebem uma oportunidade e não respeitam!" etc.

Descrever é analisar, distinguir. Aquele que descreve tem alguma possibilidade de distinguir o acontecimento da representação do acontecido enquanto repercussão sobre si mesmo (sentimentos). O barulho é barulho, distinto da perturbação que causa a mim e aos outros. Assim, a descrição produzida em diário de campo, elemento fundamental do trabalho etnográfico a que se filia a observação participante, foi fundamental para recuperar o equilíbrio, empreender constantemente a colocação de limites sem romper a parceria até chegar ao resultado final, o lançamento do livro.

A nova identidade ou "identidade terceira" para todos nós construía-se quando os atores saíam do "treino", chamando-se pelos nomes dos personagens (Manos Flores dos Anjos) ou participavam do destino deles - vão fazer "concelho", de novo?! Era o "batismo" do grupo de teatro. Ao assumirem os personagens, improvisando-os na intriga proposta, criticando, sugerindo substituições, 
Criatividade e história, entre a ação e o discurso

meus parceiros foram atores, autores e, sempre, leitores. Completar a obra do autor pelo leitor, um ato implícito e anônimo na leitura silenciosa acontece, explicitamente, na oficina de teatro e história.

O lançamento de Assim nasceu a Rua da Praia aconteceu na feira do livro de 2001, com muitos autógrafos, uma primeira entrada de direitos autorais, e apenas duas apresentações. Eu não poderia dedicar, ao trabalho de campo, nem um minuto a mais, sob pena de não cumprir o prazo de doutoramento.

\section{Teatro e história}

Assim nasceu a Rua da Praia é uma narrativa construída por improvisação dramática, codificada como ficção, visando outra, produzida nas interrupções ("congelamento"), tanto da improvisação dramática quanto da encenação. Ela é evocação, presentepassado-presente, contém elementos tanto documentais quanto de análise da primeira, sempre em parceria. É uma narrativa "segunda e principal", como apontou Sandra Pesavento.

O cuidado historiográfico com que se engendrou a narrativa em código ficcional foi suficiente para produzir "congelamentos" de evocação e análise, pertinentes à ação histórica e a indícios correspondentes.

Patriarcado e família na vila

Pobreza, violência, abandono. Isso não é tema de muita conversa na vila. Emerge quando há crise ou necessidade de mostrar a história para informar demandas sociais. "O que é ruim, quando se fala, pega".

Anos 90, Porto Alegre, v. 12, n. 21/22, p.333-367, jan./dez. 2005 
Improvisávamos os personagens, a família Flores dos Anjos, a situação de imigração relacionada ao morgadio (só o primogênito herda) e ao patriarcado.

Expliquei: conservar os filhos por perto dá poder político, orgulho do nome. Então, o pai ou o morgado ajeita pelo casamento.

- O que o pai estaria sentindo por não haver terras e a família ter de se separar? - perguntei.

- Olha, "sora", eu nem conheci meu pai e ele nunca ajudou

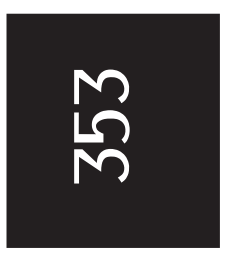
nóis (AND).

- Eu também, eu também (adolescentes).

- A minha mãe é que sempre deu tudo pra nóis (ELI).

- A minha também! O meu pai nem me registrou (CA).

- Meu pai morreu. Se deixasse alguma coisa, ia ser uma latinha de cerveja amassada (CD).

Fizemos silêncio. Pensei: pais rejeitam crianças em todas as classes. Pensei também nos casebres, sempre em obras. Só as registrara como sinal de pobreza. Então, valorizei as pequeninas obras. Consegui dizer: as mães de vocês são guerreiras...

Depois improvisamos algumas conseqüências para quem desobedecia aos pais quanto ao casamento.

"Representações" - abaixo-assinados

NARRADOR O rei se comprometera com o transporte ao Brasil, mas três anos se passaram e nada de navio. [...] Quem vendeu o que tinha, esperando viajar em seguida, já não tinha mais nada. Havia o perigo de uns e outros roubarem para se alimentarem. Ninguém agüentava mais. Então os açorianos tomaram providências (Os atores, durante a fala do narrador, se dispõem estrategicamente, dentro da platéia) 
Criatividade e história, entre a ação e o discurso

MARIO Povos dos Açores! Chegou a hora de agir. O rei tem de honrar seus compromissos. Todos pensarem tudo e ao mesmo tempo não dá. Por isso nós, chefes de família nos juntamos e escolhemos representantes. Que um deles venha e apresente as idéias que formaram.

REPRESEN-

TANTE (Lê um pergaminho que desenrola) Todos formou a seguinte idéia: de que se faça uma representação assinada pelo povo. Que a Câmara de nosso município mande mensageiro entregá-la à corte.

Todos os que estão na lista para a viagem, formem acampamento nos terrenos da Câmara e só saiam dali quando vier o navio. [...]

NARRADOR O abaixo-assinado e o acampamento? Tudo verdade verdadeira! Os historiadores encontraram esses documentos, com mais de duzentos anos, guardados nos arquivos. Agora, como eles fizeram? Quem tomou a iniciativa? Foi um "concelho" de chefes de família, houve ou não houve consultas ao povo? Isso não se sabe...

Perguntei: - Quem já deu uma de açoriano por aqui e participou de algum abaixo-assinado ou coisa parecida? Quer contar um pouquinho pra gente como é que foi isso?

- "A gente fez um pelo rango. O feijão surfava no caldo. Melhorou um tempo e depois ficou tudo igual" (CD).

- "Outro que fizeram foi pra tirar um diretor muito chato" (AND).

- "E o grêmio estudantil?", Perguntei.

Entre risadas, contaram que haviam feito uma chapa: a das gurias era para valer, a dos guris era só de oposição, mas deu briga

Anos 90, Porto Alegre, v. 12, n. 21/22, p.333-367, jan./dez. 2005 
na das gurias, que se pegaram (ELI). Os guris reivindicavam a construção de uma piscina para o colégio. No final, a eleição foi suspensa.

Perguntei: - E o orçamento participativo?

- "Querem aparecer, se largar candidato" (adolescentes).

- E o Conselho Tutelar?

- "Eles querem se dar bem", responderam-me os adolescentes, referindo-se ao salário de conselheiro, mais de 1.000 reais. Continuei: - Nunca conseguiram nada com abaixo-assinado?

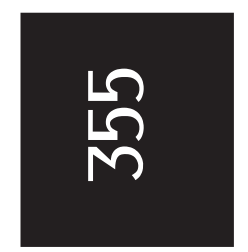

- A iluminação da vila foi. Mas orçamento participativo, a gente não entende. Fui à plenária com a Diretora. A gente não entende (VIN).

\section{A "rua" e a Rua da Praia como espaço público}

Desde a luta pela imigração (representações ao rei) até a partida dos açorianos, diálogos e narração resultaram de improvisações dramáticas. Depois, já iniciada na linguagem do grupo, cheguei a uma primeira versão do texto. Tratava-se de retornar à improvisação a partir dele, para nova versão. Revelou-se, então, o gosto do grupo pela leitura partilhada. Fez-se o silêncio. Cada um se aplicava em ler seu personagem melhor do que o outro. Os tropeços eram execrados: "burro! Volta pra primeira"!

VIZINHA 2 Três léguas ao sesmeiro, ao Dom Jerônimo de Ornellas, e a gente só recebe terra nas Missões

VIZINHA 1 Desaforo!

VIZINHA 3 Tem gente que ficou lá com ele, trabalhando na terra dele, prefiro mil vezes ser peão do rei. ${ }^{4}$

VIZINHA 4 Ainda bem que somos artífices, se não, era ali, ó, comendo na mão de D. Jerônimo. 
Criatividade e história, entre a ação e o discurso

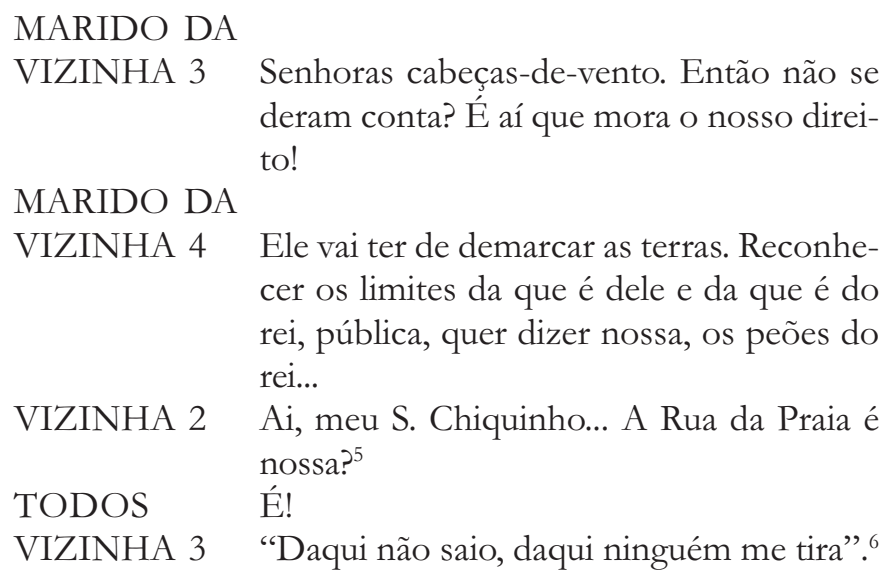

Quiseram saber o que era essa "tal de sesmaria". Expliquei que o rei doava grandes terras, três léguas, aos homens que pudessem fazer grandes fazendas, criações e plantações, que tivessem muitos escravos ou muitos trabalhadores para fazer o serviço... Todos falavam ao mesmo tempo. - Não entendo, gritei.

- "O rei largou os açorianos e deu terra pro grandão"!

Voltaram à Rua da Praia pela marchinha de carnaval, "Daqui não saio...". Não conheciam. Disse-lhes que as avós, as pessoas mais antigas, deveriam conhecer... Cantei uma pequena estrofe: "Daqui não saio, daqui ninguém me tira, mais onde é que eu vou parar, o senhor tenha paciência de esperar, inda mais com sete filhos, onde é que vou morar". Imediatamente, os meninos criaram a percussão com as garrafas "pet", de refrigerante, e as meninas botaram "samba no pé". Depois do lanche, voltamos para a cena com a questão: "Por que a Rua da Praia era deles"? "Não podiam tocá eles dali. A terra era do rei, não era do grandão".

JACINTA (Soam os tambores) Na capela, na capela, depressa...

NARRADOR Dom Agostinho Castel Branco, dos casais das ilhas, morador no Porto do Dorneles, 
foi morto à traição, com cinco facadas e algumas pancadas e as costelas quebradas, seu corpo escondido pelo matador José Raimundo, filho do mesmo Dorneles. (congelamento da cena)

A leitura interrompeu-se no atestado de óbito. "Não se entende", diziam eles. Falavam assim, naqueles tempos, expliquei. Alguns aplicavam-se ao texto, outros cantavam pagode. Primeiro, alguém pensou que o filho do sesmeiro José Raimundo matara o próprio pai. Implacáveis, os que entenderam, condenaram o equivocado a retornar à primeira série. Divergiam: uns achavam que o documento não deveria aparecer "mal escrito, ninguém ia entender nada". Outros sustentaram que a peça era de "história". Devia aparecer como foi escrito na época. Interferi dizendo que o texto explicaria o ocorrido. Continuamos.

Verdade verdadeira, o atestado de óbito está lá, no arquivo da Cúria Metropolitana, ao lado da catedral.

VIZINHA 3 Imagina! Os Ornellas! Jerônimo e a filha, até foram padrinhos de criança nossa. ${ }^{8}$

VIZINHA 4 Vai ver que o filho agiu sem conhecimento do pai.

VIZINHA 2 O rei é que tem obrigação conosco, seus peões. Ele é que deve botar essa gente de três léguas no seu lugar.

VIZINHA 3 Alimentar os tantos que vêm se chegando para cá, exige aumentar as roças...

VIZINHA 4 Os Ornellas não querem saber que o nosso porto cresça, se cresce vira freguesia, tem de doar as terras pela lei. ${ }^{9}$

NARRADOR Para os historiadores, o assassinato de D. Agostinho teria acontecido porque o crescimento do porto atrapalhava seus rebanhos, eu penso que pode ter sido pela questão dos limites entre a terra pública e a dele... 
Criatividade e história, entre a ação e o discurso

Mas então, como se não faltasse mais nada, houve guerra na Europa. No quem fica com quem, Espanha e Portugal ficaram opostos. Guerra lá e guerra aqui.

Em 1763, os espanhóis caíram no Rio Grande do Sul. Tomaram as Missões, em cima e São Pedro do Rio Grande, em baixo, a praia do Rio Grande, que também chamam Cassino.

- ... deram terra pro grandão, depois deram terra pros índios, não deram terra pra eles e agora mataram um! ${ }^{10}$

- Síntese e tanto! Pensei orgulhosa de meus parceiros.

As próximas cenas foram polêmicas, quanto aos fatos e à narrativa.

MINISTRO 2 E aos açorianos, peões do rei, que juntemse em Taquari onde receberão as terras e gêneros prometidos pelo rei.

MINISTRO 3 Isso, isso. Por terra e pela vila vão animarse e meter-se no caminho dos castelhanos.

MINISTRO 1 (tem um ataque de loucura) Vocês acham que o povo é burro? (Estapeia todos os ministros) Como é que vão surrar os espanhóis e os sesmeiros ao mesmo tempo?!. [Chora] Eles também querem fazer festa, chutar o balde!

MINISTRO 2 Leva, leva. (o Ministro 1 sai esperneando) (Na capelinha de São Francisco, o "concelho" dos açorianos está reunido).

JOÃO Dessa vez os espanhóis são brasa prá nosso assado

MANOEL Assado de quem? Receber terra na mira deles?

AFONSO Os primeiros a se encontrar no outro mundo seremos nós.

JOÃO Este é o ponto. Não se vai ao Taquari. ${ }^{11}$

Anos 90, Porto Alegre, v. 12, n. 21/22, p.333-367, jan./dez. 2005 


\section{Maria Luiza Martini}

MANOEL É isto. Quem está aqui no porto e na Rua da Praia, não vai a nenhum lugar que não seja...

JOÃO A Rua da Praia e o porto.

Criticaram os açorianos: "não fazem nada!" Não viam a recusa de juntar-se em Taquari como resistência. Retomei a invasão espanhola, perguntando qual seria o problema do governo. Alguns disseram que era dar terra para os açorianos. Houve reação em

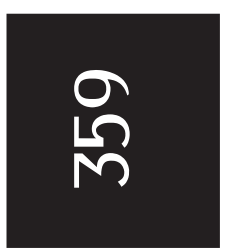
coro contra essa fala, de onde se chegou a que: "o rei não se importava com eles, só se fossem servir de sanduíche deles"...

A expressão "chutar o balde", que aprendera com o grupo, também foi questionada: "eles não falavam assim naquele tempo". Argumentei que a história dos açorianos era o enredo, mas que a peça, além do enredo, também era sua explicação. Para explicar uma história do século XVIII não seria preciso falar como naquele tempo. Embora não muito convencido, o grupo prosseguiu a leitura para chegar ao fim da história.

\begin{tabular}{|c|c|}
\hline JOÃO & $\begin{array}{l}\text { (Entra esbaforido) Nosso porto já é cape- } \\
\text { la }\end{array}$ \\
\hline JACINTA & Papel passado!? \\
\hline JOÃO & $\begin{array}{l}\text { Mais: o governador ordenou a desapro- } \\
\text { priação. Mais: teremos um mestre constru- } \\
\text { tor naval (ouve-se o tambor. Todos cor- } \\
\text { rem a ver) }\end{array}$ \\
\hline VIZINHA 3 & S. Chico eu só não desmaio... \\
\hline TODAS & $\begin{array}{l}\text { Porque todas queremos ver. (Passam os } \\
\text { sesmeiros presos) }\end{array}$ \\
\hline JACINTA & Será que o mundo virou de ponta cabeça? \\
\hline MARIA & Botou a cabeça no lugar. \\
\hline MANOEL & $\begin{array}{l}\text { Foram presos (os sesmeiros) porque de- } \\
\text { sobedeceram ao governador. }\end{array}$ \\
\hline JOÃO & $\begin{array}{l}\text { Recusavam-se a fazer a reunião da Câma- } \\
\text { ra na casa dele }\end{array}$ \\
\hline
\end{tabular}


Criatividade e história, entre a ação e o discurso

TODOS Na casa do rei!

Não se demoraram sobre a desapropriação: "o grandão teria de dar a terra para os açorianos". Queriam o fim, saber se dessa vez eles "iam se dar bem".

AFONSO (Entra correndo) Manos, somos freguesia em 26 de março de 1772.

TODOS Portoalegre-se

AFONSO Mas tem um porém.

TODOS Ah...

MANOEL Que história é essa de porém...

JOÃO Uma coisinha que não é bem como a gente quer

LÚCIA Já viu que alegria de pobre dura pouco ou tem porém...

AFONSO E é com nosso São Xico

VIZINHA 2 Anda, diga lá.

AFONSO O nosso santo tem de ser trocado pela Santa do Vice-rei. ${ }^{12}$

VIZINHA 1 Malvadeza. É só pra não dar o braço a torcer.

MARIA Vai outro abaixo-assinado

Interromperam a leitura. Passou-se o tempo de sentir o silêncio. Antes que o grupo se manifestasse, entrei com a fala seguinte:

SÃO XICO (Ouve-se sua voz como se viesse do céu) Afilhados queridos. A santa do Vice-rei é a rainha de todos. Nossa Senhora da Madre de Deus. Chega de assinar. Portoalegremse cada vez mais!

Davam sinal de cansaço, já se escutava algum pagode, uns falavam, outros gritavam. Quando encerrava a sessão de trabalho, surgiu uma fala articulada:

Anos 90, Porto Alegre, v. 12, n. 21/22, p.333-367, jan./dez. 2005 
- A sora (professora) inventou um final feliz, ou é de verdade? (ELI).

- Verdade, verdadeira, Porto Alegre é município, freguesia, desde 26 de março de 1772, data do aniversário da cidade. Os casais ou suas famílias, dentro das ordens do rei, que ainda estavam por aqui, receberam terras. Outros, não encontrados, que sumiram, foram substituídos...

- Mas tem invenção, o santo, ele aparecer (ELI)...

- É da peça, disse eu. Os Manos Flores dos Anjos são in-

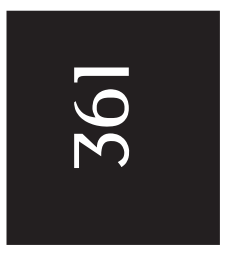
ventados, mas representavam os açorianos, verdadeiros. Das histórias muito antigas, sobram poucos documentos, como os abaixoassinados, o atestado de óbito de D. Agostinho, as petições...

Meus parceiros, mais interessados na verossimilhança puseram-se a inventariar "invenções", entre elas uma que já fora discutida nas improvisações:

- Os açorianos eram brancos, não eram?

- Sim.

- E a gente é tudo neguinho.

- Mas a história é de todos, disse eu.

\section{Conclusão}

Para atingir uma narrativa historiográfica, culturalmente codificada, segundo Ricoeur, é preciso respeitar o caráter abstrato e fragmentário da probabilidade, no limite do "quase personagem". A intriga onde ele atua não imita mas demonstra, denominandose, por isso, "quase intriga". O principal, entretanto, é que o historiador seja o senhor da narrativa, indivisível, presente em toda a urdidura do texto, implícita ou explicitamente, sendo a ele imputada toda a responsabilidade pela verdade.

Teoricamente o teatro épico pode aproximar-se da narrativa historiográfica assim concebida, com seus personagens sociais e o 
Criatividade e história, entre a ação e o discurso

narrador-historiador. Mas permanece a questão do código cultural, do sinal que orienta a expectativa do leitor sobre a história como verdade e do teatro como invenção. É nesse sentido que o grupo de teatro reage ao final: "a sora inventou um final feliz ou é verdade? Mas tem invenção, o santo aparecer...” Portanto, o trabalho produziu uma estória e uma história. Uma, dramática, sobre a história da Rua da Praia. Outra, historiográfica, do grupo de teatro, sob a forma de incidentes vividos e comentários feitos por meus parceiros, suas identidades protegidas pelo anonimato, umas delas com algum sabor a Heródoto.

Buscando a narrativa historiográfica adequada à obra aberta, em que a fragmentação da modernidade deixaria narrar-se, Benjamim opta por Heródoto e sua retórica, no início da história, como escrita da verdade. Heródoto não despreza fatos, inclusive os não presentes, o sonho e o oráculo, que se produzem na ordem do imaginário. O testemunho e a memória, sob evocação, constituem para ele documentos, tanto quanto registros escritos.

A opção de Benjamim reitera-se na radicalidade do objeto e dos documentos da Nova História Cultural, formulada fundamentalmente por Le Goff. Vários objetos, em vários campos de estudo, podem trazer o imaginário como elemento de análise e a arte como documento, mas os objetos recortados pelo imaginário enquanto "tradução não reprodutiva", criadora, poética, sempre incidirão sobre a arte como documento, seja a Mona Lisa, o Bumba meu boi, o Casamento na Roça, a Senhora do Destino, o "vamos fazer um teatro", ou a pequena literatura da "história da sua vida".

Notícia de meus parceiros: um deles terminou o segundo grau, cinco estão em vias de fazer o mesmo, um ainda não conseguiu terminar o segundo grau. Três conseguiram emprego e deixaram a escola. Um envolveu-se com tráfico. 
Maria Luiza Martini

\section{Creativity and history, between action and discourse}

Abstract. This article starts from a project related to the most spread narrative forms into an illiterate community. The drama reveals itself to the members of the Vila Pinto (Viamão/RS), where the study was realized, as an instrument for pleasure as much as a form to expose their own problems. For instance we assume the hypothesis that through the epic theatre would be developed some capacities to write the history. This was possible associating the text and the dramatization with a group of teenagers who through this could relate the story of one of the most ancient parts of the City named Rua da Praia. The product of the experience was a construction of a transcendental identity, a group of theatre who create a double text: the first is fictional and the second, historiographic comments on the first.

Keywords: Historiografic border. Epic theater. Popular accounts.

\section{Notas}

${ }^{1}$ Grupo de teatro inglês, com uma tradição de vanguarda, então liderado por Julien Beck e Judith Malina, que propunham o teatro na vida.

${ }^{2}$ Contava com um apoio institucional, um convênio entre a Universidade e o Município, com o objetivo de adaptar um trabalho que já realizara sobre origens da Rua da Praia, para público infanto-juvenil. Daí colocar a condição de inserir-me numa escola de vila popular para desenvolver o projeto.

${ }^{3}$ Ver Ricoeur (1994, p. 281, 289).

${ }^{4}$ Os imigrantes açorianos, os "casais do rei", ao se dirigirem ao Brasil, a partir de 1750, tinham as Missões como destino, aberto pelo Tratado de Madri. A nova fronteira portuguesa passava a incluir aquela região, expulsando os Missioneiros. Os indígenas rejeitaram o tratado lutando contra Portugal e Espanha. Guerra, guerrilhas e novos acordos diplomáticos fecharam o destino dos açorianos. Com a devolução das Missões para a Espanha, sem espaço alternativo, eles se concentraram nos espaços públicos.

${ }^{5}$ Em 1754, é confirmada a Sesmaria de Jerônimo de Ornelas, devendo demarcá-la determinando os limites entre a sua e a terra pública, confirmando o caminho da beira-rio, ou da Praia “... Nos rios que forem navegáveis ficará meia légua de terra livre para uso público...” (Carta de Sesmaria apud Paranhos, 1940, p. 1004). Peões do rei, trabalhadores de ofício ou de ocupação comprovada, tinham a prioridade de ocupação destes espaços. Um deles é a beira-rio, no porto dos Dorneles. A maior parte dos casais ruma para Missões atrás das terras prometidas, mas alguns se deixam ficar restabelecendo a saúde, trabalhando no porto, cultivando os espaços

Anos 90, Porto Alegre, v. 12, n. 21/22, p.333-367, jan./dez. 2005 
Criatividade e história, entre a ação e o discurso

agricultáveis. Outros trabalhavam em terras dos sesmeiros sob acordo, como é o caso de Xico da Azenha (Martini, 2002, p. 33).

${ }^{6}$ Marchinha de Carnaval. De Paquito e Romeo Gentil, data de composição nãoidentificada, gravação de 1983. Ver Martini (2001).

${ }^{7}$ A partir de 1755 , a deserção e a fuga, diante da guerra guaranítica de resistência ao tratado de Madri, provavelmente gerou um refluxo de população para o porto.(ib. id). Don Agostinho seria uma liderança da comunidade, negociando a difícil vizinhança entre cultivos na terra pública e o gado do sesmeiro. Foi assassinado conforme consta do Atestado de óbito de Dom Agostinho Castel-Branco]. [Porto Alegre]: 8 nov. 1760. Localizado em: primeiro livro de óbitos da Capela de Viamão.

${ }^{8}$ Manoel e Tereza Dorneles, filhos de Gerônimo, foram padrinhos da primeira criança açoriana nascida no porto. Ver Fortes (1932, p. 127).

${ }^{9}$ As cartas de sesmaria previam: "e mandando sua majestade criar vila naquele distrito dará terras para Rocio, e bens do Concelho (Câmara Municipal) e passando as ditas terras e pessoas eclesiásticas, pagarão pelos dízimos..." O rocio e bens do conselho destinavam-se à edificação de prédios administrativos e equipamentos públicos tais como pastos ou roças comunais na "faxina" ou periferia. Podia, ou não, a Câmara ceder parte destas terras aos particulares ou aforá-las? Tal matéria sempre foi largamente controvertida, no Brasil Colonial, para se fixar até que ponto ia os direitos da Câmara de doar as terras de seu patrimônio. Ver Martini (2002, p. 34).

${ }^{10}$ Referiam-se à Aldeia dos Anjos (Gravataî) dada para uma fração de índios missioneiros cooptados por Gomes Freire de Andrade em 1758 (Martini, 2002, p. 35).

11 “[...] enquanto ao que diz respeito aos ilhéus que se acham dispersos e que nesta forma não são de proveito algum, aqueles estabelecimentos, ordena S.M. [...] nomear dois ou três homens, de preferência militares ou civis investidos de autoridade para intimar os colonos a saírem dos lugares onde estavam arranchados." (Furtado apud Fortes, 1932, 176). A população açoriana recusou a intimação do poder metropolitano: evacuar os terrenos públicos concentrando-se em uma única povoação (uma espécie de campo de refugiados no caminho dos espanhóis), Taquari, na linha de defesa das riquezas de Viamão, em 1763 : “[...] o povo nestas faltas discorre com atrevimento [...] estes ilhéus e mais alguns moradores, todo o seu ponto é passarem o Taquari, sendo-me preciso por guardas a embaraça-los." (Pereira Pinto apud Osório, 1990, p. 103).

12 "Nos consta ser muito do agrado do Ilmo Sr Marquês Vice-rei que a Igreja Matriz da nova vila de Porto Alegre tenha a invocação de Nossa Senhora Madre de Deus, pela especial devoção, que tributa a esta senhora, como sua Madrinha: Desejando Nós conformar-nos com a pia e devota intenção do Vice-rei [...] e satisfazer quanto nos é possível a sua vontade: Havemos por bem de mudar a invocação de São

Anos 90, Porto Alegre, v. 12, n. 21/22, p.333-367, jan./dez. 2005 
Maria Luiza Martini

Francisco, que até agora tinha a referida nova Freguesia [...] no lugar do Porto dos Casais do distrito de Viamão, que ora fica sendo Vila de Porto Alegre, para a de Nossa Senhora Madre de Deus." (Monteiro, 1976, p. 212).

\section{Referências}

BARTHES, Roland. O óbvio e o obtuso; ensaios críticos III. Rio de Janeiro: Nova Fronteira, 1990. 284 p.

BENJAMIN, Walter. Magia e técnica, arte e política. São Paulo: Brasiliense, 1996. 253 p. (Obras Escolhidas, 1).

Sobre alguns temas em Baudelaire. In: BENJAMIN, Walter. Charles Baudelaire, um lírico no ange do capitalismo. São Paulo: Brasiliense, 1995. 277 p. (Obras Escolhidas, 2).

BRECHT, Bertolt. Écrits sur le Théatre. Paris: L’Arche, 1968. 364p.

FORTES, João Borges. Casaes. Rio de Janeiro: [s. e.] 1932. 268 p.

GAGNEBIN, Jeanne Marie. Walter Benjamin ou a história aberta. In: BENJAMIN, Walter. Magia e técnica, arte e política. São Paulo: Brasiliense, 1994.

FERREIRA GULLAR. Cabra marcado para morrer. In: Os melhores poemas de Ferreira Gullar. São Paulo: Global, 1983.

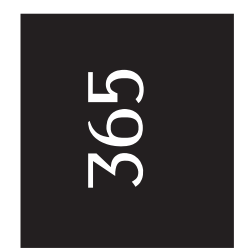

GUARNIERI, Gianfrancesco. Arena conta Zumbi. São Paulo: Teatro de Arena, 1965.

GUIMARÃES ROSA, João. A hora e vez de Agusto Matraga. In:

GUIMARÃES ROSA, João. Sagarana. Rio de Janeiro; São Paulo: Record, 1984. $386 \mathrm{p}$.

HALBWACHS, Maurice. Memória coletiva. São Paulo: Vértice. 1990.189 p.

HARTOG, François. O espelho de Heródoto; ensaio sobre a representação do outro. Belo Horizonte: UFMG, 1999. 165 p.

LE GOFF, Jacques História e memória. São Paulo: Unicamp, 1990. 552 p.

. O imaginário Medieval. Portugal: Estampa, 1994. 366 p.

A bistória nova. São Paulo: Martins Fontes, 1993. 318 p.

Anos 90, Porto Alegre, v. 12, n. 21/22, p.333-367, jan./dez. 2005 
Criatividade e história, entre a ação e o discurso

LEENHART, Jacques. As luzes da cidade. Nota sobre uma metáfora urbana em Jorge Amado. In: PESAVENTO, Sandra (Org.). Escrita, linguagem e objetos. São Paulo: EDUSC, 2004. Cap. 5, p. 147-164.

MARTINI, Maria Luiza. Teatro e História; uma experiência de Historiografia. 2002. 250f. Tese (Doutorado em História) - Instituto de Filosofia e Ciências Humanas, Programa de Pós Graduação em História, Universidade Federal do Rio Grande do Sul, Porto Alegre, 2002.

MONTEIRO, Jônathas do C. R. A dominação espanhola no Rio Grande no Sul. In: SIMPÓSIO COMEMORATIVO DO BICENTENÁRIO DA RESTAURAÇÃO DO RIO GRANDE DO SUL 1776 - 1976, Porto Alegre, 1979. Anais do Simpósio Comemorativo do Bicentenário da Restauração do Rio Grande do Sul 1776-1976. Rio de Janeiro: Instituto Geográfico Militar do Brasil, 1979.

OSÓRIO, Helen. Apropriação da terra no Rio Grande de São Pedro e a formação do espaço platino. 1990. Dissertação (Mestrado em História) - Curso de Pós Graduação em História, Universidade Federal do Rio Grande do Sul, Porto Alegre, 1990.

PARANHOS. Antunes de. Porto Alegre no século XVIII. In: CONGRESSO SUL-RIO-GRANDENSE DE HISTÓRIA E GEOGRAFIA, 3, Porto Alegre, 1940. Anais do III Congresso Sul-Rio-Grandense de História e Geografia. v. 3, p. 1039 1069.

PESAVENTO, Sandra. O desfazer da ordem fetichizada: Walter Benjamim e o imaginário social. Revista de Cultura Vozes, Rio de Janeiro, v. 89, n 5, p. 34-44, set./ out. 1995.

Escrita, linguagem e objetos. São Paulo: EDUSC, 2004.

Culpado ou inocente? De crimes, testemunhos, verdades e versões na aplicação da justiça. In: ENCONTRO ESTADUAL DE HISTÓRIA, VII, Pelotas, 2004. Anais... Porto Alegre: ANPUH/RS, 2004.

Sepé Tiaraju das Missões. In: CONGRESSO EUROPEO CEISAL DE LATINOAMERICANISTAS, 2004. Universidade de Economia de Bratislava.

Fronteiras e intertextualidade em $O$ Continente, de Érico Veríssimo. In: CHIAPPINI, Lígia; MARTINS, Maria Helena; PESAVENTO, Sandra. Pampa e cultura. Porto Alegre: Ed. UFRGS, 2004. 285 p.

RICOEUR. Paul. Tempo e narrativa. Campinas: Papirus, 1994. Tomo I. 327p.

Anos 90, Porto Alegre, v. 12, n. 21/22, p.333-367, jan./dez. 2005 


\section{Maria Luiza Martini}

RIDENTI, Marcelo. Cultura e política. Os anos 1960-1970 e sua herança. In: FERREIRA, Jorge; ALMEIDA, Lucilia. Neves Delgado de (Org.). O Brasil republicano; o tempo da ditadura. Rio de Janeiro: Civilização Brasileira, 2003. Livro 4, p. 133-166.

VANGELISTA. Chiara. "Meu tio o iauaretê": um homem-onça nas fronteiras brasileiras. In: DE DECCA, Edgar; LEMAIRE, Ria. Pelas margens; outros caminhos da história e da literatura. São Paulo; Porto Alegre: UNICAMP; Ed. da UFRGS, 2000.

VEYNE, Paul. Como se escribe la historia. Madrid: Alianza, 1984. 238p.

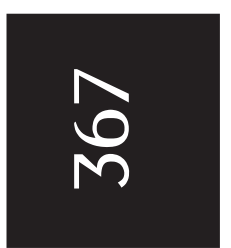

WINNICOTT. Donald Woods. Escritos de pediatria y psicoanálisis. Barcelona: Laia, 1981. 439p.

Jen et realité. Paris: Gallimard, 1975. 240 p.

Recebido em 05/01/2005.

Aprovado em 13/08/2005. 